\title{
„Margir ungir karlmenn vita ekki að pað er hægt að vera karlkyns sjúkraliði“ Áskoranir og tækifæri í starfi karlkyns sjúkraliða
}

\author{
Hermína Huld Hilmarsdóttir og Ingólfur Ásgeir Jóhannesson \\ Abstract $\longrightarrow$ Um höfunda $\quad$ About the authors $>$ Heimildir
}

Umfjöllunarefni greinarinnar er karlkyns sjúkraliðar og störf peirra á vettvangi par sem langflest starfsfólk er kvenkyns og var meginrannsóknarspurningin hver reynsla karla væri af starfi sjúkraliða. Tekin voru viðtöl við átta karlkyns sjúkraliða á ólíkum aldri snemma árs 2017. Reynsla viðmælenda var sú að karlar gætu sinnt nærgætinni umönnun og peir væru jafn færir um að sýna fagmennsku og alúð og konurnar í starfinu. Pótt peir væru ánægðir með starfið var reynsla peirra innan kvennastéttar í samræmi við margvíslegar staðalmyndir og kynhlutverk í samfélaginu. Niðurstöður gefa til kynna að í nánast öllum páttum er lutu að starfinu var hægt að sjá einhvers konar afleiðingar eðlishyggju í samfélaginu um að starfið væri kvennastarf. Ekki síst kom petta í ljós hvað fordóma varðar, til dæmis pegar notendur pjónustunnar eða aðstandendur voru tortryggnir körlum í starfinu, eða pegar sett var jafnaðarmerki á milli pess að vera karl og eiga að hafa meiri afkastagetu en konurnar. Viðmælendurnir virtust pó ekki taka pá fordóma sem peir mættu nærri sér. Pegar peir voru inntir eftir hvers vegna ekki væru fleiri karlar í stéttinni, og hvort rétt væri að reyna að fjölga peim og pá hvernig, nefndu peir gjarnan leiðir sem tengdust hugmyndum um karlmennsku og eðlishyggju, svo sem meiri ábyrgð og hærri laun.

Efnisorð: Sjúkraliðar, karlkyns sjúkraliðar, kyn, karlmennska, vinnustaðir

\section{Inngangur}

Vinnumarkaðurinn á Íslandi er mjög kynskiptur. Hann er kynskiptur eftir atvinnugreinum, eftir pví hver rekur starfsemina (opinberir aðilar eða einkaaðilar) og stöðu innan stofnana og fyrirtækja, par sem karlar eru fleiri meðal stjórnenda en konur (sjá til dæmis Ástu Dís Óladóttur o.fl., 2019). Gjarnan er talað um störf sem karla- eða kvennastörf. Oft er litið pannig á að tveir priðju eða fleiri purfi að tilheyra öðru kyninu í starfi til að kalla megi starfið karla- eða kvennastarf (Ingólfur Ásgeir Jóhannesson, 2004; Nefnd um efnahagsleg völd kvenna, 2004). Dæmi um slík karlastörf eru smíðar og forritun (Gyða Margrét Pétursdóttir, 2009; Katrín Björg Ríkarðsdóttir og Ingólfur Ásgeir Jóhannesson, 2012). Til kvennastarfa teljast flest störf tengd einhvers konar umönnun, svo sem mörg störf í heilbrigðisgeiranum og störf kennara í leik- og grunnskólum.

Konur hafa pó sótt inn í ýmis störf sem eingöngu voru skipuð körlum áður. Par má nefna læknastéttina á Íslandi en konur hafa farið frá pví að vera ein árið 1917 í að vera um rúmlega 45\% af stéttinni árið 2020 (Embætti landlæknis, e.d.; Háskóli Íslands, 2012). Konur eru nú í miklum meirihluta í störfum par sem áđur ríkti jafnræði, eins og til dæmis starfi grunnskólakennara par sem karlar voru 60\% um miðja síðustu öld (Loftur Guttormsson og Ólöf Garðarsdóttir, 2012) en voru aðeins 17,5\% miðað við 2019 (Hagstofa Íslands, e.d.). Körlum hefur síður fjölgað í kvennastörfum, hvort heldur í starfi leikskólakennara eða kvennastarfa meðal heilbrigðisgreina. 
Í pessari grein er sjónum beint að körlum í stétt sjúkraliða. Um er að ræða hóp sem starfar á fjölbreyttum vettvangi innan heilbrigðiskerfisins og víðar. Starfið felst einkum í að veita fólki pá aðstoð eða aðhlynningu sem á parf að halda (Sjúkraliðafélag Íslands, 2011). Sjúkraliðar á Íslandi voru tæplega 3000 árið 2016, pegar rannsóknin var undirbúin, par af aðeins 71 karl eða um 2,4\% (Kristín Á. Guðmundsdóttir, munnleg heimild, 20. september 2016). ${ }^{[1]}$ Menntun sjúkraliða er sex anna nám á framhaldsskólastigi eða 206 framhaldsskólaeiningar og er hægt að stunda námið í a.m.k. tíu framhaldsskólum í öllum landshlutum (Sjúkraliðafélag Íslands, 2011). Um fjórðungur námsins er almennt bóknám, annar fjórðungur almennar heilbrigðisgreinar og tæpur helmingur sérhæfðar bóklegar greinar og vettvangsnám (sjá til dæmis Fjölbrautaskólann í Breiðholti, e.d.; Fjölbrautaskólann við Ármúla, 2016).

Í rannsókn pessari voru í ársbyrjun 2017 tekin viðtöl við átta karla innan sjúkraliðastéttarinnar í pví augnamiði að kanna aðstæður peirra í stéttinni og viðhorf. Aðalrannsóknarspurningin er: Hver er reynsla karla af starfi sjúkraliða? Auk pess eru fjórar undirspurningar sem fengist er við: Hvers vegna velja karlar sjúkraliðastarf? Hvaða áskoranir og tekifari mata körlum i starfi sjúkraliða? Mata karlarnir fordómum i starfi og samfélagi? Hver eru viðhorf karlkyns sjúkralida til fjölgunar karla innan stéttarinnar? Rannsókn sem pessi hefur ekki verið gerð áður meðal sjúkraliða en meðal annarra íslenskra kvennastétta, til dæmis meðal hjúkrunarfræðinga (Pórður Kristinsson, 2003, 2005) og leikskólakennara (Anna Elísa Hreiðarsdóttir, 2006).

\section{Bakgrunnur}

Í umræðum um kyn takast gjarna á tvenns konar sjónarmið; annars vegar eðlishyggjusjónarmið par sem fólki er ætlað tiltekið eðli út frá pví í hvaða kynlíkama fólk fæðist (Francis, 2001), hins vegar mótunarsjónarmið par sem pví er hafnað að hlutverk, staða og hegðun kynjanna séu meðfædd heldur mótist einstaklingar af umhverfi sínu og í samskiptum við annað fólk (Francis, 2001; Ingólfur Ásgeir Jóhannesson, 2004; Schwandt, 1997). Hugtökin karlmennsku og kvenleika parf að skoða í ljósi beggja sjónarmiða. Eðlishyggjusjónarmið gera ráð fyrir að eðlislægir eiginleikar segi til um sterkar og veikar hliðar kynjanna, par með taldar hliðar sem hafa áhrif á starfsval. Karlar eða konur eru ef til vill útilokuð frá ákveðinni menntun eða starfsvettvangi par sem vafi leikur á um getu peirra (Guðný Guðbjörnsdóttir, 2007; Paechter, 2007). Ef litið er til mótunarhyggju eru hæfileikar fólks til að sinna ákveðnum störfum ekki taldir meðfæddir eiginleikar heldur pykja karlmennska og kvenleiki vera til marks um hugmyndir sem mótast í orðræðu samfélagsins um hvaða útlit, hegðun og störf hæfi körlum og konum (Cross og Bagilhole, 2002; Doucet, 2004; Ingólfur Ásgeir Jóhannesson, 2004).

Í ljósi viðfangsefnis greinarinnar er litið sérstaklega til hugmynda um karlmennsku (Connell og Messerschmidt, 2005; Ingólfur Ásgeir Jóhannesson, 2004). Pað pykir vera til marks um karlmennsku að vera sterkur, sýna ekki tilfinningar og hafa völd, til dæmis í formi peninga eða veraldlegra hluta eins og að eignast dýran bíl eða eiga alltaf kærustu (Atherton-Zeman, 2013; Dworkin og Messner, 2002; Jón Ingvar Kjaran og Ingólfur Ásgeir Jóhannesson, 2010; Paechter, 2007). Petta eru dæmi um viðteknar karlmennskuhugmyndir (e. hegemonic masculinity), sem koma gjarnan fram á tvo vegu (Connell og Messerschmidt, 2005). Annars vegar í formi innri ríkjandi karlmennsku, sem vísar til peirrar forréttindastöðu sem peir karlar sem að henni búa hafa fram yfir aðra karla. Hins vegar er talað um ytri ríkjandi karlmennsku sem vísar til peirra stofnanabundnu yfirráða sem karlar, sem að henni búa, hafa yfir konum (Connell og Messerschmidt, 2005). Andstæða karlmennskunnar í pessu hugtakapari er auðvitað kvenleikinn, helst af öllu styðjandi kvenleiki (e. emphasized femininity) (Gyða Margrét Pétursdóttir, 2012; Schippers, 2007), sem felur í sér veika stöðu og fyrst og fremst að stöðu karla sé ekki ógnað með pví sem konurnar hugsa og gera.

Kynjakerfi samfélagsins byggist á hugmyndum af pessum toga (Walby, 1997; Porgerður Einarsdóttir, 2006). Kynjakerfið hefur pó breyst og pað virðist vera orðið auðveldara fyrir pessi tvö kyn, sem oftast eru tilgreind ( og Stefansen, 2015; Gentry og Harrison, 2010; Gottzén, 2011). Í inngangi var til dæmis nefnt að 
konur hefðu í ríkari mæli sótt í hefðbundin karlastörf, til dæmis sem læknar, og pað á við um mörg önnur karlastörf. Рað virðist pó ganga hægar fyrir karla að hasla sér völl í kvennastörfum. Líklega hefur valdastaða par mikið að segja; karlar hafa síður viljað sækja inn á vettvang kvenna. Mögulegt er að laun og hugmyndir um laun spili par inn í; karlastörfin hefðbundnu hafa verið betur launuð en hefðbundin kvennastörf og pví eftir meiru par að sækjast á nýjum vettvangi fyrir konur.

Hugtökin glerpak (e. glass ceiling) og glerrúllustigi (e. glass escalator) hafa verið notuð til að lýsa hvernig karlar og konur mæta kynjakerfinu á margvíslegan og ólíkan hátt (Amudha o.fl., 2016). Glerpakið vísar til pess að konur eiga í meiri erfiðleikum með að vinna sig upp í starfi en karlar og eru síður ráðnar í stjórnunar- og yfirmannsstöður. Glerrúllustiginn vísar til pess að karlar fái frekar forskot pegar peir vinna á kvennavinnustöðum, jafnvel hærri laun og eigi auðveldara með að komast í yfirmanna- og stjórnunarstöður en konur á karlavinnustöðum (Amudha o.fl., 2016; Katrín Björg Ríkarðsdóttir og Ingólfur Ásgeir Jóhannesson, 2012).

Hér verða nefnd nokkur dæmi úr rannsóknum af reynslu karla í hefðbundnum kvennastörfum (Bagilhole og Cross, 2006; Cushman, 2009; Hardie, 2015; Lupton, 2006). Peir geta lent í erfiðleikum sökum starfsvals síns og má pá nefna að karlkyns hjúkrunarfræðingar fundu fyrir að peir voru ekki taldir geta verið umhyggjusamir, að peim væri ekki eðlislægt að hjúkra (Inoue o.fl., 2006). Körlum sem sinntu í hjúkrun í Âstralíu pótti erfiðast að sinna nærgætinni hjúkrun við kvenkyns skjólstæðinga er peir purftu að fara inn á einkasvæði viðkomandi. Svo erfiður reyndist peim pessi páttur starfsins að karlar voru fjórum sinnum líklegri til að skipta um starfsvettvang en kvenkyns hjúkrunarfræðingar (Inoue o.fl., 2006). Körlum innan sjúkraliðastéttarinnar í Danmörku fannst pað skipta miklu máli að sjúkraliðastarfið ætti sér svo langa sögu sem kvennastarf. Peim fannst peir purfa að læra allt tengt umönnun sem var konunum eðlislægara (Cottingham, 2016; Hundborg og Hall, 2003). Рað gerði að verkum að körlum fannst peir purfa að halda fast í sín karllægu gildi á sama tíma og peir sýndu umhyggju, og pá sérstaklega karllægan samveru- og samræðustíl, bæði við samstarfsmenn og sjúklinga. Körlunum fannst erfiðast að átta sig á ólíku gildismati kynjanna og vegna pess hversu ólíkt pað var pá fannst peim peir ekki vera metnir að verðleikum af kvenkyns yfirmönnum sínum (Hundborg og Hall, 2003). Einnig fundu karlar í kvennastörfum fyrir að peir væru taldir sérvitrir, misheppnaðir, kvenlegir, aumingjalegir eða samkynhneigðir (Cushman, 2009; Lupton, 2006; Pórður Kristinsson, 2005). Eigin fordómar virðast einnig hafa áhrif á hvort karlar halda til streitu námi í hjúkrun (Pórður Kristinsson, 2005).

Karlar í kvennastéttum hafa verið spurðir út í ástæður fyrir starfsvali sínu (Cushman, 2009; Pórður Kristinsson, 2003). Mjög mörgum fannst mikilvægt að vera góð fyrirmynd og að hafa möguleikann á að skilgreina karlmennsku eftir öðrum viðmiðum en með ríkjandi karlmennsku eins og peim fannst vera algengasta viðmiðið. Sumir sóttust eftir frama á ákveðnu sviði og enn aðrir töluðu um löngunina að vinna með fólki, leggja eitthvað af mörkum og pá lífsfyllingu sem viðkomandi starf gaf peim, ekki síst að vinna með fólki. Pá sögðust aðrir fyrst og fremst hafa upplifað leiða sem fylgdi hefðbundnum karlastörfum eða að peir hefðu ekki fundið sig í peim og peir hefðu pví ákveðið að breyta til (Bagilhole og Cross, 2006; Cushman, 2009; Lupton, 2006; Pórður Kristinsson, 2003, 2005). Einnig komu við sögu hugmyndir varðandi breytingar á viðhorfum til kynhlutverka; pað væri ekki endilega litið á störf með peim hætti að pau væru aðeins ætluð öðru kyninu (Hardie, 2015; Lupton, 2006). Ef ungir karlar áttu vini bæði meðal karla og kvenna voru peir opnari fyrir að fara í kvennastörf og að samstarfsfólk og jafningjar peirra væru konur (Hardie, 2015; Lupton, 2006). Auk pess væru ýmsir aðrir kostir, sem stæðu lítið menntuðum körlum til boða, ekki endilega fýsilegir (Bagilhole og Cross, 2006; Cross og Bagilhole, 2002; Hardie, 2015; Lupton, 2006).

\section{Аðferð}

Til að rannsaka reynslu karla pótti viðtalsrannsókn liggja beint við par sem viðtöl í anda eigindlegra aðferða henta vel pegar reynsla fólks og líðan er skoðuð (Helga Jónsdóttir, 2013). Margs konar viðtöl eru til og í pessu tilviki var notaður viðtalsrammi með opnum spurningum. 


\section{Pátttakendur}

Haustið 2016 hafði fyrri höfundur greinarinnar samband við Sjúkraliðafélag Íslands og sagði frá fyrirætlunum um rannsóknina. Félaginu leist vel á hugmyndina og bauðst til að greiða götu pegar kæmi að pví að fá pátttakendur til liðs við verkefnið. Snemma í janúar 2017 sendi félagið bréf með pátttökubeiðni til karla á félagaskrá sinni, sem voru á aldrinum 25-45 ára. Pessi beiðni skilaði aðeins tveimur viðmælendum. Pví var einnig leitað að pátttakendum á samfélagsmiðlum og auglýsingavefnum „Bland“ og óskað eftir aðstoð einstaklinga, sem pekktu persónulega karla í sjúkraliðastéttinni. Einnig komu til liðs vinir rannsakandans, sem pekktu karla innan starfsgreinarinnar, og spurðu pá hvort peir hefðu áhuga á að taka pátt. Aldursbil pátttakenda, sem komu á pann hátt við sögu, var breiðara en sá hópur sem fékk sent bréf. Aðferðirnar sem voru notaðar við að finna pátttakendur eru vel pekktar. meðal annars undir nöfnunum sjálfboðaliðaúrtak og snjóboltaúrtak (Katrín Blöndal og Sigríður Halldórsdóttir, 2013). Saman eru pær gagnlegar til að ná fjölbreyttum hópi viðmælenda (Seidman, 1998).

Að lokum urðu viðmælendur átta karlar, allir menntaðir sjúkraliðar. Pátttakendurnir voru flestir á aldrinum frá prítugu til rúmlega fimmtugs pegar viðtölin voru tekin í janúar og febrúar 2017, en einn var að ljúka störfum vegna aldurs. Allir nema einn voru búsettir á höfuðborgarsvæðinu eða í um klukkustundar akstursfjarlægð frá pví. Fimm peirra störfuðu pá sem sjúkraliðar en prír höfðu bætt við sig annarri menntun, par af höfðu tveir aflað sér menntunar í annarri starfsgrein innan heilbrigðiskerfisins. Viðmælendurnir höfðu starfað mislengi sem sjúkraliðar, og höfðu brautskráðst á árunum 1995-2015 en fóru ekki alltaf strax að vinna við sjúkraliðastarfið. Starfsreynsla peirra var frá tveimur árum í rúm 20 ár.

Hvert viðtal var á bilinu 30-45 mínútur að lengd, samtals rúmar fimm klukkustundir. Pau voru hljóðrituð, einstök atriði punktuð niður og síðan afrituð orðrétt (Helga Jónsdóttir, 2013). Tilbúin nöfn eru notuð pegar vitnað er í orð viðmælenda.

\section{Greining}

Við greiningu gagnanna var lögð áhersla á að koma auga á mynstur og pemu í hugmyndum og frásögnum viðmælendanna. Um er að ræða fyrirbæralýsingu (e. phenomenography) annars vegar og fyrirbærafræði (e. phenomenology) hins vegar. Раð fyrrnefnda fjallar um að skilja hvernig fólk hugsar um ákveðna hluti og fyrirbæri en hið síðarnefnda um að skoða reynslu einstaklinga með opnum huga (Sigríður Halldórsdóttir, 2013).

Svör viðmælenda voru borin saman til að athuga hvort par væri sameiginleg eða ólík reynsla til staðar sem myndað gæti meginpemu og stuðst við verklag sem Lichtman (2013) mælir með. Pessi pemu voru flokkuð og urðu pannig til peir meginpættir sem undirspurningarnar, sem settar voru fram hér að framan, fela í sér. Textinn var marglesinn, lagaður að hverju pema fyrir sig og efnisatriði flutt til svo frásagnir af reynslu karlanna yrðu eins og lýsandi og unnt væri. Pó skal tekið fram að ekki var hvert pema einróma skoðun allra viðmælenda heldur bendir hvert pema aðeins til pess að pað hafi komið ítrekað fram eða að nægilega mörgum hafi fundist tilefni til að nefna pað. Pannig varð grundvöllur til að draga viðkomandi atriði fram og leiða hugann að pví. Úr pessu efni var skrifuð frásögn út frá hverjum pætti fyrir sig og fóru höfundarnir margsinnis yfir niðurstöður og túlkun peirra.

\section{Gildi rannsóknarinnar og siðferðilegir pættir}

Í rannsókninni var helstu venjum eigindlegra rannsókna fylgt eftir. Fjöldi viðmælenda var svipaður og algengt er í rannsóknum af pessu tagi. Peir voru jákvæðir fyrir rannsókninni en höfðu pó mismikið ígrundað reynslu sína af að vera karl í sjúkraliðastarfi. Í síðustu viðtölunum kom minna af nýjum upplýsingum en í peim fyrri sem gerði að verkum að nokkur mettun náðist (Katrín Blöndal og Sigríður Halldórsdóttir, 2013). Fyrri höfundurinn, sem tók viðtölin, er sjúkraliði með umtalsverða starfsreynslu, pekkti pví starfsvettvanginn og gat á pann hátt metið frásagnir viðmælenda, sem talið er mikilvægt (Sigríður Halldórsdóttir og Sigurlína Davíðsdóttir, 2013). 
Viðmælendum var kynntur tilgangur rannsóknarinnar og meðferð viðtalsgagnanna, og peir gátu pví tekið upplýsta ákvörðun um pátttökuna. Viðmælendur eru fagfólk og teljast par af leiðandi ekki viðkvæmur hópur. Karlkyns sjúkraliðar eru hins vegar frekar fáir, samtals aðeins nokkrir tugir eins og fyrr segir. Til að vega upp á móti peim möguleika að viðmælendur pekkist úr hópnum er lýsingum á einstökum atburðum og staðháttum haldið í lágmarki og jafnvel hnikað lítils háttar til eins og tíðkast ef leyna parf hverjir viðmælendur eru.

\section{Niðurstöður}

Í fyrsta undirkafla er fjallað um bakgrunn viðmælenda og hvers vegna peir völdu starfið. Í öðrum kafla er umfjöllun um upplifun peirra af sjúkraliðastarfinu. Driðji kaflinn er um fordóma sem viðmælendur höfðu upplifað á starfsferlinum. Fjórði og sỉðasti undirkaflinn er um leiðir sem viðmælendur töldu færar til pess að fjölga körlum í stéttinni.

\section{Hvers vegna völdu viðmælendur starfið?}

Bakgrunnur viðmælenda reyndist fjölbreyttur og fyrir utan áhuga peirra á heilbrigðisgeiranum lágu ólíkar ástæður að baki vali peirra á námi. Sumir beinlínis „enduðu“ í náminu, stundum eftir að hafa sinnt umönnunarstörfum, fremur en að stefnan hefði verið sett pangað. Helmingur viðmælenda hafði unnið innan heilbrigðiskerfisins við ýmiss konar umönnun og pví lá beint við að læra til sjúkraliða. Til dæmis sagði Finnur:

Ég var búinn að vinna við umönnun í nokkur ár pegar ég fór í námið. Fyrst á [staður hérlendis] og síðar í [erlendis] og líkaði pað mjög vel pannig að ákvörðunin varðandi námið kom eiginlega af sjálfu sér, langaði til að læra meira og tryggja mig í starfi ...

Pá kom fram að margir viðmælendur höfðu litið svo á að sjúkraliðanámið væri góður grunnur fyrir frekara nám, til dæmis hjúkrunarfræði eða annað nám innan heilbrigðisgeirans. Peir sem hugðu á frekara nám vissu einnig að í sjúkraliðanáminu gætu peir fengið grunninn að „anatómíunni“ (pað er líffærafræðinni), sem margir kviðu fyrir í hjúkrunarnámi.

Viðmælendur voru spurðir hvort peir hefðu verið ánægðir með námið, og svöruðu allir játandi. Peir sögðu að kennararnir, sem voru í öllum tilvikum konur og hjúkrunarfræðingar að mennt, hefðu sýnt fagmennsku. Peir sögðust ekki hafa fundið fyrir að kennarar eða samnemendur peirra kæmu öðruvísi fram við pá vegna kyns síns. Ingvar sagði:

Ég bjóst alveg við pví að pær yrðu miklu betri við mig eða miklu verri við mig, hötuðu mig eða elskuðu mig. En ... hún var bara eins við mig og hina nemendurna. Pær máttu alveg eiga pað, pær voru eins við allan hópinn.

Sumir viðmælendur tóku pó fram að námsbækurnar hefðu verið nokkuð kvenmiðaðar og peim fannst pað virka fráhrindandi. Ari sagði:

Pað er í námsefninu öllu gert ráð fyrir pví að pað sé kona sem er að læra námsefnið og pað er svolítið fráhrindandi ...

Kvenmiðað kennsluefni var atriði sem karlar í hjúkrun komu einnig inn á í rannsóknum Pórðar Kristinssonar $(2003,2005)$, pað er að í kennslubókum sé gert ráð fyrir að hjúkrunarfræðingar og sjúkraliðar séu konur.

Hér hefur verið bent á að staða á vinnumarkaði hafi ráðið miklu um starfsval viðmælenda. Margir peirra höfðu, eins og Hardie (2015) hefur gert grein fyrir, ekki fundið hefðbundið karlastarf sem peim líkaði og par af leiðandi höfðu peir unnið ýmis störf áður en peir lögðu sjúkraliðastarfið fyrir sig. Petta kom einnig fram hjá viðmælendum okkar; pá langaði að vinna lifandi starf sem væri einnig gefandi. Pessar niðurstöður vísbendingu um að kynhlutverk hafi hugsanlega breyst. Viðmælendur 
litu svo á að peir pyrftu ekki að sætta sig við hefðbundna karlavinnu ef hún hentaði peim ekki. Peir gátu valið sér starf sem krafðist bæði nándar og nærgætni, jafnvel pótt starfið félli ekki að viðhorfum ríkjandi karlmennsku.

\section{Áskoranir og tækifæri í sjúkraliðastarfinu}

Í viðtölunum komu fram nokkur atriði um hvernig væri að vera karl í starfi sjúkraliða. Í fyrsta lagi fannst viðmælendum gæta misræmis á milli náms og vinnumarkaðar, og höfðu pá tilfinningu að kannski væri prátt fyrir allt ekki gert ráð fyrir körlum í stéttinni. Í öðru lagi var rætt um ábyrgð sjúkraliða í sínu starfi og í priðja lagi vægi launa.

Flestir viðmælenda töldu að peim hefði verið vel tekið á vinnustöðum. Samstarfsfólk peirra hefði fagnað pví að fá karl í stéttina og peir væru jafn mikill hluti af hópnum og peir kærðu sig um. Prátt fyrir pað virtist ekki alltaf vera gert ráð fyrir körlum í stéttinni. Búningsaðstaða var til dæmis stundum ekki til staðar fyrir karla heldur einungis búningsaðstaða fyrir konurnar. Í sumum tilvikum höfðu peir purft að notast við baðherbergi eða fara í vinnufötin heima, eða aðstaðan var mjög pröng, til dæmis sagði Ingvi: „Svo er náttúrulega búningsaðstaðan, hún er svona einn fimmti af fermetra ..." Viðmælendur virtust pó ekki taka petta mjög nærri sér en voru sammála um að petta myndi sennilega ekki líðast ef konur kæmu inn á karlavinnustað. Davíð sagði:

Ég var náttúrulega bara ungur og fannst ekki skipta neinu máli pó ég skipti um föt inni á einhverju klósetti, skilurðu.

Einnig ræddu viðmælendur um að vinnufatnaður ætti pað til að vera eingöngu með kvensniði og passaði illa, til dæmis væru jakkar með brjóstasniði.

Útskrifaður sjúkraliði kom út á vinnumarkaðinn með pekkingu sem hann síðan bætti jafnt og pétt við, bæði með reynslu og viðbótarnámi. Pó fannst viðmælendum að sú ábyrgð sem sjúkraliðar bæru og pau störf sem peim væri treyst fyrir ekki alltaf vera í samræmi við pá menntun og reynslu sem peir byggju yfir. Viðmælendur nefndu að oft væri pað undir deildarstjóranum komið hverju sinni hversu mikla ábyrgð peir fengju. Viðmælendur vildu margir sjá skýrari verkferla um störf sjúkraliða og hvert peirra hlutverk væri. Fram kom pó að breytingar væru í rétta átt um verksvið og ábyrgð sjúkraliðanna. Grímur sagði:

Ég hef unnið á [ónefndum stað] og par var pér treyst fyrir öllu. Pú tókst til lyfin og gafst pau, pú lagðir upp pvagleggi, ég setti upp nálar ...

Viðmælendur voru sammála um að laun fyrir starfið væru alltof lág. Starf sjúkraliða var að peirra mati mikilvægt starf, að pví leyti að pað snerist um umönnun og fólk. Launin væru pví ekki í samræmi við mikilvægi starfsins eða pað álag sem pví fylgdi.

Viðmælendur tóku fram að pað væri fleira sem skipti pá máli en launin, til dæmis vinnutími og vinnuaðstaða. Nefnt var að petta starf fæli hvorki í sér að vinna í „ryki og mengun“ eins og til dæmis í álveri, né krefðist pað pess að einstaklingur pyrfti að vinna úti í öllum veðrum, eins og til dæmis í byggingarvinnu. Ari sagði:

Ég er bara að segja pað að maður getur alveg sætt sig við pínulítið lægri laun á einhverjum forsendum sem maður býr sér til sjálfur.

Prír viðmælendanna höfðu bætt við sig annarri menntun og ein af ástæðum pess að peir fóru að líta í kringum sig voru launin. Prátt fyrir að taka öll möguleg námskeið til að ná fram hækkunum fannst peim peir fljótt vera komnir upp í topp og gátu ekki hækkað meira. Davíð sagði:

Launin eru náttúrulega stór partur pess að maður fór að hugsa sér eitthvað annað pví að pað er einfaldlega ekki hægt að lifa á peim ... Ég meina pað er auðvitað hægt að fá ágætan pening en pú parft pá að vinna rosalega mikið til pess. 
Sumir viðmælendanna sögðu frá pví að peir hefðu lesið sér til um hvernig mögulegt væri að hækka launin með pví að bæta við sig námskeiðum, og hefðu pví farið gagngert í pað ferli. Pá hefði samstarfsfólk ályktað sem svo að hækkunin væri vegna kyns peirra en ekki sökum pess að peir hefðu unnið að pví með pví að sækja námskeiðin. Davíð sagði:

Pá fór að kvisast út á vinnustaðnum að karlmaður fengi að sjálfsögðu hærra borgað en konurnar, pað hafði sem sagt einhver komist að pví að ég hefði hærra kaup en margar aðrar ... En pað var enginn sem hafði áhuga á að vita út af hverju, pað var af pví að ég var karlmaður fannst peim. Og svona fólk var mjög fljótt að ákveða fyrir fram að af pví að ég væri karlmaður pá fengi ég einhver sérréttindi.

Petta er líklega dæmi um hvernig hinn svokallaði glerrúllustigi getur virkað, pegar karl kynnir sér vandlega framgangsmöguleika hvað laun varðar.

Að mati viðmælenda voru karlar boðnir velkomnir í starfið og almenn ánægja virtist ríkja með að fá karl á viðkomandi vinnustað. Á sama tíma virtist sem vinnumarkaðurinn og vinnustaðirnir væru ekki samstíga og ekki gert ráð fyrir peim pegar peir væru komnir á staðinn. Vinnufatnaður með kvensniði og ófullnægjandi búningsaðstaða fyrir karla gaf óbeint til kynna að starfið væri aðeins ætlað konum. Að ætlast til pess að karlar klæddust kvenfatnaði gerði lítið úr karlmennsku peirra og mátti tengja viðhorfum til kynhlutverka (Hardie, 2015; Lupton, 2006). Viðmælendum okkar virtist pað ekki vera mikilvægt að framganga peirra samræmdist ríkjandi karlmennskuhugmyndum um að karlar undirstrikuðu völd með peningum og veraldlegum hlutum (Dworkin og Messner, 2002; Gentry og Harrison, 2010).

\section{Fordómar - í starfi og samfélagi}

Fordómar geta komið fram á hvaða vettvangi eða í hvaða aðstæðum sem er, og er starf karla í sjúkraliðastarfinu engin undantekning. Viðmælendurnir sögðust allir hafa upplifað einhverja fordóma í starfi sínu sem sjúkraliðar, einkum snemma á starfsferli sínum. Skipta má peim fordómum, sem viðmælendurnir urðu fyrir, í prennt eftir pví hvaðan peir komu; frá samstarfsfólki, skjólstæðingum og samfélagi.

Minnihluti viðmælenda hafði fundið fyrir fordómum frá samstarfsfólki sínu. Ari sagði sagði pó að „afköst" sín hefðu verið vefengd:

Ég var búinn að vera töluvert uppi að sinna veikum manni, kem síðan niður og pá eru pær farnar að gefa mér illt augnaráð og svo kemur ein að mér og spyr: „Hversu marga ert pú búinn að hátta í kvöld?" Pá voru pær greinilega búnar að vera að láta pað gerjast á milli sín að ég væri ekki búinn að afkasta nógu ...

Viðmælendurnir töldu að peir hefðu yfirleitt fljótt verið metnir að verðleikum. Pekking og fagleg vinnubrögð voru pað sem skipti helst máli. Samstarfsfólk leit á pá sem hluta af hópnum og peir voru ávallt spurðir álits eða kallað eftir aðstoð peirra ef pess purfti, jafnt á við annað starfsfólk.

Flestir viðmælendur könnuðust við fordóma frá skjólstæðingum. Yfirleitt voru peir aðeins við fyrstu kynni. Peir komu helst frá ungum körlum, eldri konum og aðstandendum eldri kvenna. Ungum körlum fannst undarlegt að hafa karl í umönnunarstarfi; áttu pað til að vísa til pess að sjúkraliðinn hlyti að vera samkynhneigður án pess hafa hugmynd hver kynhneigð sjúkraliðans væri. Ívar sagði:

Í byrjun, sérstaklega, og fyrir [meira en 20] árum voru karlmenn ekki svona hluti af stéttinni ... og ungu mennirnir og strákarnir sérstaklega kölluðu mann bara homma.

Ívar sagði enn fremur að pað hefði aðeins verið rétt á meðan peir voru að venjast tilhugsuninni um karl í starfinu. Enn fremur sagði hann að pað hefði verið tiltölulega auðvelt að slá pá umræðu út af borðinu með pví að slá á létta strengi og tala um hvað væri gaman að vinna í stórum kvennahópi. 
Eldri konur höfðu einnig tilheyrt peim hópi fólks sem pótti erfitt að njóta nærgætinnar umönnunar pegar karl átti í hlut. Aðstandendur eldri kvenna hefðu einnig farið hjá sér fyrir peirra hönd og talið að viðkomandi myndi ekki vilja aðstoð karls við persónulega umhirðu. Ingvi sagði: „Рað er ein og ein kona sem er smeyk við mann en maður tekur pví alveg með ró." Fordómar frá skjólstæðingum virtust pví hafa lítil áhrif en engu að sîđur purftu viðmælendur okkar að vera við pví búnir að mæta tortryggni. Peir höfðu próað leiðir til pess að leiða pað hjá sér eða snúa pessum páttum sér í hag.

Spurt var út í viðhorf samfélagsins. Ívar sagði:

Petta pykir kvennastarf og almenningi fannst sérstaklega skrýtið að maður væri sjúkraliði. Mér finnst miklu minna um pað en var, svona fordómar. Eins og á minni deild, ég er einn að vinna með 35 konum og sumum karlmönnum finnst pað einfaldlega ekki nógu karlmannlegt, en pað er nú samt orðið sjaldgæft að ég finni pað.

Sú umræða kom einnig upp að kannski væru pað eigin fordómar sem öftruðu körlum í pessu starfi. Ívar sagði:

Maður er að vinna við eitthvað sem maður hefur vit á og hefur gaman af pá gengur petta ákveðið og pað er ekkert verið að spá í pað. En, jú, jú fyrsta ferðin með bekken [koppur notaður fyrir pá sem eru rúmliggjandi] var mjög erfið ... en ég lét mig hafa pað ...

Prátt fyrir að telja sig vita um fordóma í samfélaginu um karla í kvennastörfum var pað ekki svo að viðmælendur upplifðu pá á hverjum degi. Pvert á móti pá var pað frekar sjaldgæft að peir fyndu fyrir fordómum í kringum sig, og í sumum tilfellum voru pað eigin fordómar sem trufluðu pá. Á meðan sumir fundu fyrir að starfið pætti ekki nægilega karlmannlegt sögðu aðrir að peir bæru aukna virðingu fyrir konum par sem starfið væri líkamlega erfitt.

Fordómar sem viðmælendur urðu fyrir áttu sér vísast rót í ólíku gildismati, samanber niðurstöður Hundborg og Hall (2003). Í sumum tilvikum var ætlast til pess að karlarnir skiluðu meiri vinnu og í einstaka tilvikum póttu peirra skoðanir ekki marktækar. Pessi atriði voru hvort tveggja dæmi um eðlishyggju. Gert var ráð fyrir ákveðnum eiginleikum sem karlar áttu að búa yfir eða gert var lítið úr peim og peir vændir um pekkingarleysi sökum kyns síns, pað er peir voru ekki taldir búa yfir pekkingu sem varðaði umönnun.

Fordómar frá skjólstæðingum komu helst fram við fyrstu kynni af sjúkraliðanum. Pað má vel vera að ástæðan tengist eðlishyggjuhugmyndum, sem enn eru við lýði í samfélaginu. Pó svo að annað kynið, karlar í pessu tilviki, væri ekki útilokað frá ákveðnum starfsvettvangi pá var oft á tíðum efast um getu peirra eða ásetning (Guðný Guðbjörnsdóttir, 2007; Paechter, 2007). Petta upplifðu karlkyns hjúkrunarfræðingar í rannsókn Cottingham (2016) einnig; peim var ekki talið eðlislægt að hjúkra.

Fordómar frá nærumhverfi voru að sögn viðmælenda hvorki miklir né ristu djúpt. Engu að síður hefði verið áskorun að standa frammi fyrir eigin fordómum eins og fram kom í rannsóknum Pórðar Kristinssonar (2005) og Inoue og félaga (2006) par sem eigin fordómar urðu til pess að karlar hættu í námi í hjúkrun.

\section{Fjölgun karla í sjúkraliðastarfi}

Við ræddum við viðmælendur hvers vegna ekki væru fleiri karlar í stéttinni og hvað peir teldu að mætti gera til pess að auka áhuga peirra á starfi sjúkraliða. Flestir voru sammála um að nauðsynlegt væri að fjölga körlum í stéttinni. Peir töldu að pað myndi breyta andrúmslofti á vinnustaðnum og kallaði fram ólíkar skoðanir og vinnubrögð.

Viðmælendur purftu flestir að hugsa sig nokkuð um pegar peir voru inntir eftir hvaða leiðir væru mögulegar til að fjölga körlum í stéttinni. Peim fannst að meta pyrfti menntun peirra meira að verðleikum pannig að hún skilaði sér í aukinni ábyrgð og hærri launum. Grímur sagði: 
Já, sko, pað má alveg fara að gera sjúkraliða, að peir fái meira að ráða verkferlunum. Sjúkraliðar eiga að geta séð um hjúkrun sjúklingsins. Sjúkraliðarnir hafa pekkinguna, peir kunna petta.

Pá nefndu viðmælendurnir að pótt viðbótarnám sjúkraliða væri gott, pá hækkuðu launin hvorki til samræmis né fylgdi meiri ábyrgð í kjölfarið. Sá sem lokið hefði viðbótarnámi ynni sömu störf og almennur sjúkraliði og jafnvel ófaglærður starfsmaður. Davíð sagði:

Par sem ég hef unnið hefur pað ekki skipt máli hvort pú ert sjúkraliði eða ófaglærður, pú vinnur í rauninni sömu störf ... pú vinnur bara pessi ófaglærðu störf og pá gleymist kannski pessi kunnátta sem [hefur] skapast ... hjá sjúkraliðum ... Nú er ég ekki að tala um laun endilega heldur meira starfssvið og ábyrgð.

Viðmælendum fannst líklegt að hærri laun ýttu undir að karlar litu á sjúkraliðastarfið sem raunhæfan möguleika. Pá vantaði einnig möguleika að ná frama í starfi, sem væri mikilvægur páttur.

Margir viðmælendur töldu að kynna pyrfti starfið betur með tilliti til pess að pað væri fyrir alla, ekki eingöngu konur. Peir sögðust hafa rekið sig á að karlar í kringum pá hefðu ekki áttað sig á að petta starf stæði peim til boða. Finnur sagði:

Margir ungir karlmenn vita ekki að pað er hægt að vera karlkyns sjúkraliði. Einn strákur sem er að vinna með mér og er í menntaskólanum hér sagði mér að pegar hann fékk vinnuna hefðu vinir hans ekki haft hugmynd um að pessi vinna væri í boði fyrir stráka.

Gömul gildi sem birtust í launamisrétti og viðhorfum pyrftu einnig að breytast, og pað tæki tíma. Starfið væri í hugum margra kvennastarf, almenningi fyndist undarlegt að karlar gegndu pessu starfi og pað væri aðeins með kynningu sem pað breyttist. Раð væri kannski einnig páttur í að margir karlar hyrfu úr aðhlynningarstörfum og færðu sig yfir í geðhjúkrun. Viðhorf samfélagsins væru einnig pess eðlis að viðmælendur veltu fyrir sér hvernig væri að eldast í pessu starfi.

Viðmælendurnir settu fram nokkrar hugmyndir að leiðum til að fjölga körlum í stéttinni en voru á sama tíma efins um að pær myndu endilega leiða til árangurs. Fyrst nefndu peir samræmi á milli menntunar, ábyrgðar og launa. Peim fannst að menntun og öll viðbótarmenntun ætti að skila sér í aukinni ábyrgð og hærri launum. Peir sögðust hafa verið meðvitaðir um að peir hefðu valið sér starfsvettvang par sem launin væru sennilega ekki mjög há. Peir heilluðust samt af honum og höfðu jafnvel unnið við umönnun áður en til kom að ná sér í réttindin. Viðmælendur sögðust einnig gera sér grein fyrir að peir tilheyrðu kvennastétt og væru pví venjunni samkvæmt á mun lægri launum er hefðbundnar karlastéttir (Katrín Björg Ríkarðsdóttir og Ingólfur Ásgeir Jóhannesson, 2012). Prátt fyrir að laun hefðu kannski ekki úrslitavald pegar kom að starfsvali, pá hefðu pau áhrif engu að síður.

Aðrar hugmyndir um fjölgun karla í starfinu sneru að samfélagslegum páttum. Sú vitneskja pyrfti að vera til staðar að sjúkraliðastarfið væri starf fyrir öll kyn. Fleiri karlar innan stéttarinnar leiddu á endanum til jákvæðara viðhorfs almennings, sem drægi smám saman úr eðlishyggjuhugmyndum samfélagsins, líkt og kom fram í grein Ingólfs V. Gíslasonar (2011) um hjúkrunarfræðinga og leikskólakennara. Kröfur samfélagsins til karlmennsku nú á dögum að vera næmur og blíður og hafa getuna til að sýna tilfinningar sínar (Brandth og Kvande, 2003; Doucet, 2004; Farstad og Stefansen, 2015; Gottzén, 2011). Sé petta merki um karlmennsku er petta einnig merki um að karlar séu færir um að sinna störfum par sem einmitt pessir eiginleikar eru mikilvægir.

\section{Ályktanir og lokaorð}

Í greininni hefur verið leitast eftir að svara hver sé reynsla karla af starfi sjúkraliða. Komið hefur fram að viðmælendur voru ánægðir með starfið en jafnframt að reynsla peirra innan kvennastéttar virtist vera í samræmi við margvíslegar staðalmyndir og kynhlutverk í samfélaginu. Nánast allir pættir sem 
til skoðunar voru báru vott um einhvers konar afleiðingar eðlishyggju í samfélaginu og að starfið væri aðallega kvennastarf prátt fyrir að nokkrir karlar sinntu pví líka.

Reynsla viðmælenda var sú að karlar gætu sinnt nærgætinni umönnun og væru jafn færir um að sýna fagmennsku og alúð og konurnar í starfinu. Petta er í samræmi við pann veruleika að flestir karlar sinna nú á tímum bæði börnum sínum og heimilisverkum. Pannig sýna peir eiginleika sem áđur voru aðeins ætlaðir konum, til dæmis umhyggju og natni (Brandth og Kvande, 2003; Connell og Messerschmidt, 2005; Doucet, 2004; Farstad og Stefansen, 2015; Gottzén, 2011). Petta ætti að geta yfirfærst á störf par sem konur eru í meirihluta, par á meðal starf sjúkraliða.

Viðteknar hugmyndir um karlmennsku eiga sennilega pátt í að starfið pyki á stundum ekki nægilega karlmannlegt. Karlmennska ræðst, eins og áður hefur verið komið inn á, af orðræðu samfélagsins á hverjum tíma fyrir sig um hvað pykir hæfa körlum (Cross og Bagilhole, 2002; Doucet, 2004; Ingólfur Ásgeir Jóhannesson, 2004). Pví má ætla að karlmennskuhugmyndir samfélagsins hafi talsverð áhrif á hversu vænlegt peim pykir starfið. Pó virðist ekki hafa verið vegið eins alvarlega að karlmennskuhugmyndum viðmælenda okkar eins og kom fram í rannsókn Cross og Bagilhole (2002). Í rannsókn peirra kom í ljós að körlunum pótti peir knúnir til að umgangast „sterka“ karlahópa utan vinnu sinnar til að ná jafnvægi. Petta kom ekki fram hjá viðmælendum okkar.

Umræðan um hvort fjölga pyrfti körlum í stétt sjúkraliða - og par af leiðandi í öðrum kvennastéttum - er áhugaverð, að pví leyti að viðmælendur völdu sér pennan starfsvettvang vitandi að um kvennastétt væri að ræða. Deir höfðu áhuga á starfinu og virtust ekki taka nærri sér pá fordóma sem peir mættu. Pegar peir voru inntir eftir pví hvers vegna ekki væru fleiri karlar í stéttinni, og hvort rétt væri að reyna að fjölga peim og hvernig, nefndu peir samt sem áður helst leiðir sem tengdust hugmyndum um karlmennsku og eðlishyggju, svo sem meiri ábyrgð og hærri laun. Að auki fannst peim að kynna pyrfti starfið betur fyrir körlum og að sjúkraliðastarfið væri raunhæfur möguleiki fyrir karla.

Að fá innsýn í reynslu karla af sjúkraliðanámi og starfi er viðbót við pá kynjafræðilegu umræðu sem átt hefur sér stað undanfarin ár. Mikilvægt er að́ átta sig á sjónarhornum karla og að peir finni fyrir samfélagslegri pressu um að peir haldi sig innan ramma síns kynhlutverks. Bent var á vankanta í námsefni sjúkraliða og á vinnustöðum, sem gæti fælt karla frá starfinu, til dæmis að búningar væru með kvensniði. Petta getur vitanlega átt við um störf karla í mörgum öðrum kvennastéttum - og sama er uppi á teningnum um aðstæður kvenna í karlastéttum. ${ }^{[2]}$

\section{Aftanmálsgreinar}

1. Petta er tala yfir alla í Sjúkraliðafélagi Íslands, bæði pá sem voru starfandi og komnir á lífeyri eða hættir störfum. Lægri tala eða rúmlega 2100 er birt hjá landlæknisembættinu fyrir árið 2020 en hún nær eingöngu yfir pá sjúkraliða sem starfa á sjúkrastofnunum, dvalar- og hjúkrunarheimilum og heilsugæslustöðvum og er byggð á upplýsingum frá Sjúkraliðafélagi Îslands. Tala karla á peirri skrá er 69 eða um 3,3\% (Embætti landlæknis, e.d.) Fjöldi og hlutfall karla eru hins vegar sambærileg í bádum tölunum.

2. Ritgerðin er byggð á meistaraprófsrannsókn fyrri höfundar, sem unnin var við Háskóla Íslands undir leiðsögn síðari höfundar: Hvaða starf klæðir pig. Karlar í stétt sjúkraliða. 


\section{Many young men do not know that it is possible to be a male Licensed Practical Nurse. Challenges and opportunities for male Licensed Practical Nurses.}

The article deals with the topic of male licensed practical nurses (LPNs) and their experience in an environment almost wholly occupied by females. The main research question deals with the experience of working as a male licensed practical nurse. Other questions included are why they chose that occupation, what the challenges were and opportunities they met, whether they experienced prejudices, and what was their view towards trying to attract more males to become LPNs. This is the first study of this kind among Icelandic LPNs. There are, however, previous comparable studies among the mostly female professions of registered nurses and pre-school teachers.

Eight male licensed practical nurses of different ages were interviewed in early 2017. They were asked about their background and why they chose this field; the challenges and opportunities for them on the job; whether they had experienced prejudice on the job and socially for their choice of occupation; and whether it would be wise to try to attract more males to the field of licensed practical nursing.

Our interviewees chose this field for various reasons. Besides simply being interested in entering a health profession, some of them had kind of "ended up" studying to become an LPN rather than planning for it. They had worked in various jobs before entering their studies, jobs they had not been satisfied with. Most of them had been pleased with the studies although they tended to be forgotten as they were a tiny minority. They also mentioned that the job was satisfying and rewarding, in contrast to some of the traditional male occupations they had considered or worked at.

When we analyzed the challenges and opportunities for them as men in this occupation, our interviewees mentioned that men were not generally expected to work in this field. For instance, the working clothes had been designed for females, and at times the facilities to change clothes was very small or non-existent. They, for instance, sometimes needed to change at home before going to work. The work also offered them various opportunities and usually they were welcomed to the field of being an LPN. The interviewees' experience was that males could administer delicate care and that they were as able as females to demonstrate professionalism and amiability. Although they were pleased with their job, their experience within a female occupation was in line with societies' manifold stereotypes and gender roles. Also, among the advantages mentioned was the fact that the job did not include having to work in an environment of "dust and pollution", as in an aluminium smelter, nor did it demand working outdoors in all sorts of weather, as for example in construction.

The results indicate that in almost all factors relating to the job, the consequences of some sort of societal essentialism to the effect that the job was a woman's job, could be observed. Prejudices in this regard were obvious when for example either the users of the service or their relatives were suspicious towards men doing the job, and also when the assumption was made that being male meant that they could be more productive than females. The interviewees, however, did not seem to be bothered by the prejudices they experienced.

When asked why there were not more male licensed practical nurses and whether it would be desirable to increase their numbers and how to go about doing that, they often referred to ideas relating to masculinity and essentialism such as more responsibility and better pay. They thought that awareness of the job being suitable for both men and women needed to be raised, similarly to other jobs where care and feelings are strengths and assets to the job.

Key words: licensed practical nurses, male practical nurses, gender, masculinity, work places 


\section{Um höfunda}

Hermína Huld Hilmarsdóttir (hermina@bhs.is) er framhaldsskólakennari í Borgarholtsskóla. Hún brautskráðist sem sjúkraliði frá Fjölbrautaskóla Vesturlands á Akranesi árið 2000 og vann í 19 ár í pví starfi við Heilbrigðisstofnun Vesturlands. Hún lauk BA-prófi í félagsvísindum frá Háskólanum á Akureyri árið 2015 og M.Ed.-prófi í menntun framhaldsskólakennara frá Háskóla Íslands árið 2017. Meðal faglegra áhugasviða hennar eru félagsleg hegðun og samskipti, par með talin samskipti kynjanna.

Ingólfur Ásgeir Jóhannesson (ingo@hi.is) er prófessor við Menntavísindasvið Háskóla Íslands. Hann lauk BA- og cand.mag.-prófi i sagnfræði frá Háskóla Íslands og doktorsprófi í menntunarfræðum frá Wisconsin-háskóla í Madison. Hann hefur meðal annars sérhæft sig í rannsóknum á kyngervi og menntun.

\section{About the authors}

Hermína Huld Hilmarsdóttir (hermina@bhs.is) is an upper secondary school teacher in Borgarholtsskóli, Reykjavík. She graduated from The Comprehensive Secondary School of West Iceland as a practical nurse in 2000 and worked for 19 years in the Health Care Institution of West Iceland. She completed her BA degree in social science from the University of Akureyri in 2015 and an M.Ed. degree in upper secondary school teaching from the University of Iceland in 2017. Her professional interests include social behavior and communication, for instance of the genders.

Ingólfur Ásgeir Jóhannesson (ingo@hi.is) is a professor at the School of Education at the University of Iceland. He holds BA and cand.mag. degrees in history from the University of Iceland. He also holds a Ph.D. in curriculum and instruction from the University of Wisconsin, Madison. His research focuses, among other topics, on gender and education.

\section{Heimildir}

Amudha, R., Cresenta Shakila Motha, L., Selvabaskar, S., Alamelu, R. og Surulivel, S. (2016). Glass ceiling and glass escalator. An ultimate gender divide in urban vicinity. Indian Journal of Science and Technology, 9(27), 1-8. https://doi.org/10.17485/ijst/2016/v9i27/97620

Anna Elísa Hreiðarsdóttir. (2006). Fólk heldur að við séum fleiri. Viðtalsrannsókn við íslenska karlleikskólakennara [meistararitgerð, Háskólinn á Akureyri]. Skemman.is. http://hdl.handle.net/1946/1228

Atherton-Zeman, B. (2012). Men's manifesto 2012. Í Shira Tarrant (ritstýra), Men speak out: Views on gender, sex and power (bls.144 - 147). Routledge

Ásta Dís Óladóttir, Gylfi Dalmann Aðalsteinsson og Póra H. Christiansen. (2019). Er skortur á framboði eða er engin eftirspurn eftir konum í æðstu stjórnunarstöður? Stjórnmál og stjórnsýsla, 15(2), 205-228. http:// www.irpa.is/article/view/a.2019.15.2.4/pdf

Bagilhole, B. og Cross, S. (2006). 'It never struck me as female': Investigating men's entry into female-dominated occupations. Journal of Gender Studies, 15(1), 35-48. http://doi.org/10.1080/09589230500486900

Brandth, B. og Kvande, E. (2003). Father's presence in childcare. Í A.-M. Jensen og L. Mckee (ritstýrur), Children and the changing family: Between transformation and negotiation (bls. 61-75). Routledge.

Connell, R. W. og Messerschmidt, J. W. (2005). Hegemonic masculinity. Gender \& Society, 19(6), 829-859. https://doi.org/10.1177/0891243205278639

Cottingham, M. D. (2016). Theorizing emotional capital. Theory and Society, 45(5), 451-470. https://doi. org/10.1007/s11186-016-9278-7

Cross, S. og Bagilhole, B. (2002). Girls' jobs for the boys? Men, masculinity and non-traditional occupations. Gender, Work and Organization, 9(2), 204-225. https://doi.org/10.1111/1468-0432.00156 
Cushman, P. (2009). Male primary school teachers: Helping or hindering move to gender equity? Teaching and Teacher Education, 26(5), 1211-1218. https://doi.org/10.1016/j.tate.2010.01.002

Doucet, A. (2004). 'It's almost like I have a job, but I don't get paid': Fathers at home reconfiguring work, care, and masculinity. Fathering, 2(3), 277-302. [

Dworkin, S. L. og Messner, M. A. (2002). Just do ...? What? Sport, bodies, gender. Í S. Scraton og A. Flintoff (ritstýrur), Gender and sport. A reader (bls. 17-30). Routledge.

Embætti landlæknis. (e.d.). Heilbrigðisstarfsfólk eftir kyni 2015-2020. https://www.landlaeknir.is/tolfraedi-og-rannsoknir/tolfraedi/allt-talnaefni/

Farstad, G. R. og Stefansen, K. (2015). Involved fatherhood in the Nordic context: Dominant narratives, divergent approaches. NORMA: International Journal for Masculinity Studies, 10(1), 51-70. http://doi.org /10.1080/18902138.2015.1013348

Fjölbrautaskólinn í Breiðholti. (e.d.). Sjúkraliðabraut. http://www.fb.is/nyjar-namsbrautir/sjukralidabraut/

Fjölbrautaskólinn við Ármúla. (2016). Sjúkraliðabraut. https://www.fa.is/namid/heilbrigdisskolinn/sjukralidabraut/

Francis, B. (2001). Beyond postmodernism: Feminist agency in educational research. Í B. Francis og C. Skelton (ritstýrur), Investigating gender: Contemporary perspectives in education (bls. 65-76). Open University Press.

Gentry, J. og Harrison, R. (2010). Is advertising a barrier to male movement toward gender change? Marketing Theory, 10(1), 74-96. https://doi.org/10.1177/1470593109355246

Gottzén, L. (2011). Involved fatherhood? Exploring the educational work of middle-class men. Gender and Education, 25(5), 619-634. https://doi.org/10.1080/09540253.2010.527829

Guðný Guðbjörnsdóttir. (2007). Menntun, forysta og kynferði. Háskólaútgáfan.

Gyða Margrét Pétursdóttir. (2009). Within the aura of gender equality. Icelandic work cultures, gender relations and family responsibility. A holistic approach [doktorsritgerð]. Háskóli Íslands.

Gyða Margrét Pétursdóttir. (2012). Styðjandi og mengandi kvenleiki innan áru kynjajafnréttis. Íslenska pjóðfélagið, 3, 5-18.

Hagstofa Íslands. (e.d.). Starfsfólk við kennslu eftir kyni, landsvæðum og kennsluréttindum 1998-2019. https://px.hagstofa.is/pxen/pxweb/en/Samfelag/Samfelag_skolamal_2_grunnskolastig___gsStarfsfolk/ SKO02301.px

Hardie, J. H. (2015). Women's work? Predictors of young men's aspirations for entering traditionally female-dominated occupations. Sex Roles, 72(7-8), 349-362. https://doi.org/10.1007/s11199-015-0449-1

Háskóli Íslands (2012, 11. maí). Frumkvöðull kvenna í læknastétt. http://aldarafmaeli.hi.is/afmaeli/frumkvodull_kvenna_i_laeknastett

Helga Jónsdóttir. (2013). Viðtöl í eigindlegum og megindlegum rannsóknum. Í Sigríður Halldórsdóttir (ritstýra), Handbók i aðferðafreði rannsókna (bls. 137-154). Háskólinn á Akureyri.

Hundborg, S. og Hall, E. O. C. (2003). At være i en kvindelig verden: En eksplorativ undersøgelse af mandlige sygeplejerskers oplevelser. Vard i Norden, 23(2), 4-8. https://doi.org/10.1177/010740830302300202

Ingólfur V. Gíslason. (2011). Karlar i „kvenna“störfum. Í Ása Guðný Ásgeirsdóttir, Helga Björnsdóttir og Helga Ólafs (ritstýrur), Fjóðarspegillinn: Rannsóknir i félagsvisindum XII: Félags- og mannvisindadeild. Erindi flutt á rádstefnu i október 2011 (bls. 306-314). Félagsvísindastofnun Háskóla Íslands.

Ingólfur Ásgeir Jóhannesson. (2004). Karlmennska og jafnréttisuppeldi. Rannsóknarstofa í kvenna- og kynjafræðum.

Inoue, M., Chapman, R. og Wynaden, D. (2006). Male nurses' experiences of providing intimate care for women clients. Journal of Advanced Nursing, 55(5), 559-567. https://doi.org/10.1111/j.1365-2648.2006.03948.x

Jón Ingvar Kjaran og Ingólfur Ásgeir Jóhannesson. (2010). „Ég myndi alltaf enda með einhverri stelpu“. Eru framhaldsskólar á Íslandi gagnkynhneigðir? Ráðstefnurit Netlu-Menntakvika 2010. http://hdl.handle. net/1946/7807

Katrín Björg Ríkarðsdóttir og Ingólfur Ásgeir Jóhannesson. (2012). Er hægt að bjóða kynjakerfinu birginn? Reynsla átta kvenna af smíðum og tölvunarfræði. Netla - Veftimarit um uppeldi og menntun. http://netla. hi.is/greinar/2012/ryn/010.pdf 
Katrín Blöndal og Sigriður Halldórsdóttir. (2013). Úrtök og úrtaksaðferðir í eigindlegum rannsóknum. Í Sigríður Halldórsdóttir (ritstýra), Handbók i aðferðafraði rannsókna (bls. 129-136). Háskólinn á Akureyri.

Lichtman, M. (2013). Qualitive research in education. A users guide. Sage.

Loftur Guttormsson og Ólöf Garðarsdóttir. (2012). Íslenskir barnakennarar 1930 og 1960: Félagsleg og lýðfræðileg einkenni. Rásstefnurit Netlu - Menntakvika 2012. http://hdl.handle.net/1946/14570

Lupton, B. (2006). Explaining men's entry into female concentrated occupations: Issues of masculinity and social class. Gender, Work and Organization, 13(2), 103-128. https://doi.org/10.1111/j.1468-0432.2006.00299.x

Nefnd um efnahagsleg völd kvenna. (2004). Efnahagsleg völd kvenna. Skýrsla. Forsætisráðuneytið.

Paechter, C. (2007). Being boys being girls: Learning masculinities and femininities. Open University Press.

Schippers, M. (2007). Recovering the feminine other: Masculinity, femininity, and gender hegemony. Theory, Culture \& Society, 36(1), 85-102. https://doi.org/10.1007/s11186-007-9022-4

Schwandt, T. A. (1997). Qualitative inquiry: A dictionary of terms. Sage.

Seidman, I. (1998). Interviewing as qualitative research. A guide for researchers in eduction and the social sciences (2. útgáfa). Teachers College Press.

Sigríður Halldórsdóttir (2013). Yfirlit yfir eigindlegar rannsóknaraðferðir. Í Sigríður Halldórsdóttir (ritstýra), Handbók i aðferðafraði rannsókna (bls. 239-249). Háskólinn á Akureyri.

Sigríður Halldórsdóttir og Sigurlína Davíðsdóttir. (2013). Réttmæti og áreiðanleiki í eigindlegum og megindlegum rannsóknum. Í Sigríður Halldórsdóttir (ritstýra), Handbók i a fferðafraði rannsókna (bls. 211-228). Háskólinn á Akureyri.

Sjúkraliðafélag Íslands. (2011). Af hverju sjúkraliðanám? http://www.slfi.is/af-hverju-sjukralieanam/

Walby, S. (1997). Theorizing patriarchy. Blackwell.

Porgerður Einarsdóttir. (2006). Kynjakerfið: Úrelding í augsýn eða viðvarandi kynjahalli? Í Úlfar Hauksson (ritstjóri), Rannsóknir i Félagsvisindum VII: Félagsvisindadeild. Erindi futt á rásstefnu i október 2006 (bls. 445-456). Félagsvísindastofnun Háskóla Îslands.

Pórður Kristinsson. (2003). Kynlegir kvistir: Karlar i hjúkrun [meistararitgerð]. Háskóli Íslands.

Pórður Kristinsson. (2005). Upplifun karla á hjúkrunarnámi. Hvað stendur i vegi fyrir auknum hlut karla i hjúkrun? Jafnréttisnefnd Háskóla Îslands. https://www.hi.is/sites/default/files/atli/baeklingar/jafnretti/upplifun_karla_hjukrunarnam.pdf

Hermína Huld Hilmarsdóttir og Ingólfur Ásgeir Jóhannesson. (2021). Margir ungir karlmenn vita ekki að pað er hægt að vera karlkyns sjúkraliði“. Áskoranir og tækifæri í starfi karlkyns sjúkraliða. Netla - Veftimarit um uppeldi og menntun. https://doi.org/10.24270/netla.2021.8

Hermína Huld Hilmarsdóttir og Ingólfur Ásgeir Jóhannesson. (2021).

„Margir ungir karlmenn vita ekki að pað er hægt að vera karlkyns sjúkraliði“ Áskoranir og tækifæri í starfi karlkyns sjúkraliða

Netla - Veftímarit um uppeldi og menntun. Menntavísindasvið Háskóla Íslands.

Sótt af https://netla.hi.is/greinar/2021/alm/08.pdf

DOI: https://doi.org/10.24270/netla.2021.8 